\title{
ILHAS DE CALOR EM TERESINA-PI: EPISÓDIOS DE VERÃO
}

\author{
HEAT ISLANDS IN TERESINA-PI: SUMMER EPISODES \\ LAS ISLAS DE CALOR EN TERESINA-PI: EPISODIOS DE VERANO
}

\author{
Kleyson Campêlo de Araújo \\ Mestre em Geografia pela Universidade Federal do Piauí \\ kleysoncampelo@hotmail.com
}

Carlos Sait Pereira de Andrade

Professor adjunto da Universidade Federal do Piauí

carlossait@hotmail.com

\begin{abstract}
Resumo: Mapear ilhas de calor em evidência na cidade de Teresina, capital do estado do Piauí, constitui objetivo central deste trabalho. Utilizou-se transectos móveis combinados com pontos fixos para mensuraçóes de temperatura do ar, umidade relativa do ar e velocidade dos ventos. Essas mensuraçóes foram realizadas nos dias 03, 05, 07, 10, 12 e 14 de março de 2013. Os dados obtidos resultaram na confecção de cartas de isotermas e isoígras através de um Sistema de Informação Geográfica, que permitiram identificar ilhas de calor em diversos pontos da cidade. Uma vez que uma discussão dessa natureza enseja a análise da dinâmica meteorológica regional à compreensão da atmosfera urbana nos episódios escolhidos, embasou-se em cartas sinóticas fornecidas pelo site da Marinha do Brasil e imagens coloridas do satélite Goes 12 e13 do Centro de Previsão do Tempo e Estudos Climáticos do Instituto Nacional de Pesquisas Espaciais. A geometria urbana, a poluição de veículos automotores, os materiais de construção, os pequenos corpos hídricos, entre outros, são exemplificados como elementos do Sistema Clima Urbano teresinense capazes de compor realidades mesoclimáticas e microclimáticas singulares. Dia 03, por exemplo, formou-se célula e ilha de calor com amplitudes térmicas de $6^{\circ} \mathrm{C}$ e $4,1^{\circ} \mathrm{C}$, respectivamente.
\end{abstract}

Palavras-chave: Ilhas de calor, clima urbano, Teresina-PI, transectos móveis e Sistema de Informação Geográfica.

\begin{abstract}
Mapping heat islands in evidence in the city of Teresina, capital of the state of Piauí, is the central objective of this work. Combined mobile transects with fixed points were used to measure air temperature, relative air humidity and wind velocity. These measurements were carried out on 03, 05, 07, 10, 12 and 14 March 2013. The data obtained resulted in the preparation of temperature and humidity maps through a Geographic Information System, which allowed the identification of heat islands in several Points of the city. Since a discussion of this nature provokes the analysis of the regional meteorological dynamics to
\end{abstract}


the understanding of the urban atmosphere in the chosen episodes, it was based on synoptic charts provided by the website of the Brazilian Navy and colored images of Goes 12 and 13 satellites of the Center of Weather Forecast and Climate Studies of the National Institute for Space Research. Urban geometry, automotive vehicle pollution, building materials, small water bodies, among others, are exemplified as elements of the teresineses Urban Climate System capable of composing unique mesoclimatic and microclimatic realities. On day 03, for example, the cell and heat island were formed with thermal amplitudes of $6{ }^{\circ} \mathrm{C}$ and 4.1 ${ }^{\circ} \mathrm{C}$, respectively.

Keywords: Heat islands, urban climate, Teresina-PI, mobile transects and Geographic Information System.

Resumen: Mapear islas de calor en evidencia en la ciudad de Teresina, capital del estado de Piauí, es el objetivo central de este trabajo. Se utilizó transectos móviles combinados con puntos fijos para mediciones de la temperatura del aire, humedad relativa y velocidad de los vientos. Estas mediciones se realizaron en los días 03, 05, 07, 10, 12 y 14 de marzo de 2013. Los datos dieron como resultado la elaboración de cartas de isotermas e isoigras a través de un Sistema de Información Geográfica, que permitieron identificar las islas de calor en diversos puntos de la ciudad. Una vez que una discusión de esta naturaleza proporciona el análisis de la dinámica meteorológica regional para entender el ambiente urbano en los episodios elegidos, se basó en cartas sinópticas proveídas por el sitio de la Marina de Brasil e imágenes coloridas del satélite Goes 12 y 13 del Centro Previsión del Tiempo y Estudios climáticos del Instituto Nacional de Investigaciones Espaciales. La geometría urbana, la contaminación de los vehículos automotores, los materiales de construcción, pequeños cuerpos hídricos, entre otros, son ejemplificados como elementos del Sistema Climático Urbano de Teresina capaces de componer realidades mesoclimática y microclimáticas únicas. En el día 03, por ejemplo, célula y isla de calor se formaron con amplitudes termales de $4,1^{\circ} \mathrm{C}$ y $6{ }^{\circ} \mathrm{C}$, respectivamente.

Palabras-clave: las islas de calor, clima urbano, Teresina-PI, transectos móviles y Sistema de Información Geográfica.

\section{INTRODUÇÃO}

O Programa das Naçóes Unidas para os Assentamentos Humanos lançou em 2013 o relatório "Estado das Cidades da América Latina e Caribe". Segundo esse relatório, a América Latina é a regiấo mais urbanizada do mundo. Atualmente, quase $80 \%$ da população dessa região vivem em cidades e calcula-se que até 2020, esse percentual chegará a $90 \%$. O processo de urbanização acelerado que acometeu a América Latina nas últimas décadas está associado à construçáo de novos complexos industriais e centros comerciais. O desenvolvimento econômico das cidades fomentou um intenso fluxo humano rural-urbano, onde as transformações espaciais são inerentes a esse processo. Infelizmente, a velocidade dessas transformaçóes, associada à ausência de políticas públicas pautadas no desenvolvimento sustentável, têm sido marcadas pela deterioração do meio ambiente (HABITAT, 2013). 
Teresina, capital do estado do Piauí e localizada na região Nordeste brasileira, segue o acelerado processo de urbanizaçáo da América Latina (Figura 1). O censo demográfico realizado pelo Instituto Brasileiro de Geografia e Estatística, em 2010, revelou o Município de Teresina com uma taxa de urbanizaçáo superior à da América Latina e do Brasil. Segundo esse censo demográfico, a população absoluta municipal era de 814.230 habitantes e a taxa de urbanização de 94,2\%. O Brasil no mesmo ano possuía percentual de urbanização de $84,3 \%$. O maior contingente populacional sobre o sítio resultou na expansão da urbe teresinense para além do traçado original, planejado em 1852 por Conselheiro Saraiva, então presidente da Província do Piauí.

Há diversos problemas ambientais condicionados por essa nova realidade espacial. As derivações climáticas são exemplos. Monteiro (1969), Branco (2001), Silveira (2007), Kallas (2008), Silva (2009), Andrade (2009), Feitosa (2010) e Albuquerque (2012) analisaram algumas derivaçôes climáticas intraurbanas decorrentes desse mais acentuado processo de urbanização que acometeu a cidade teresinense nos últimos anos. Esses estudos confirmaram eficazmente o papel da verticalização, impermeabilização dos solos e de áreas verdes na composição de microclimas. Todavia, há carência de estudos holísticos que contemplem os canais de percepção humana do clima numa perspectiva mesoclimática e geográfica, pois esses autores são, em maioria, arquitetos.

Figura 1 - Mapa da Localização da cidade de Teresina

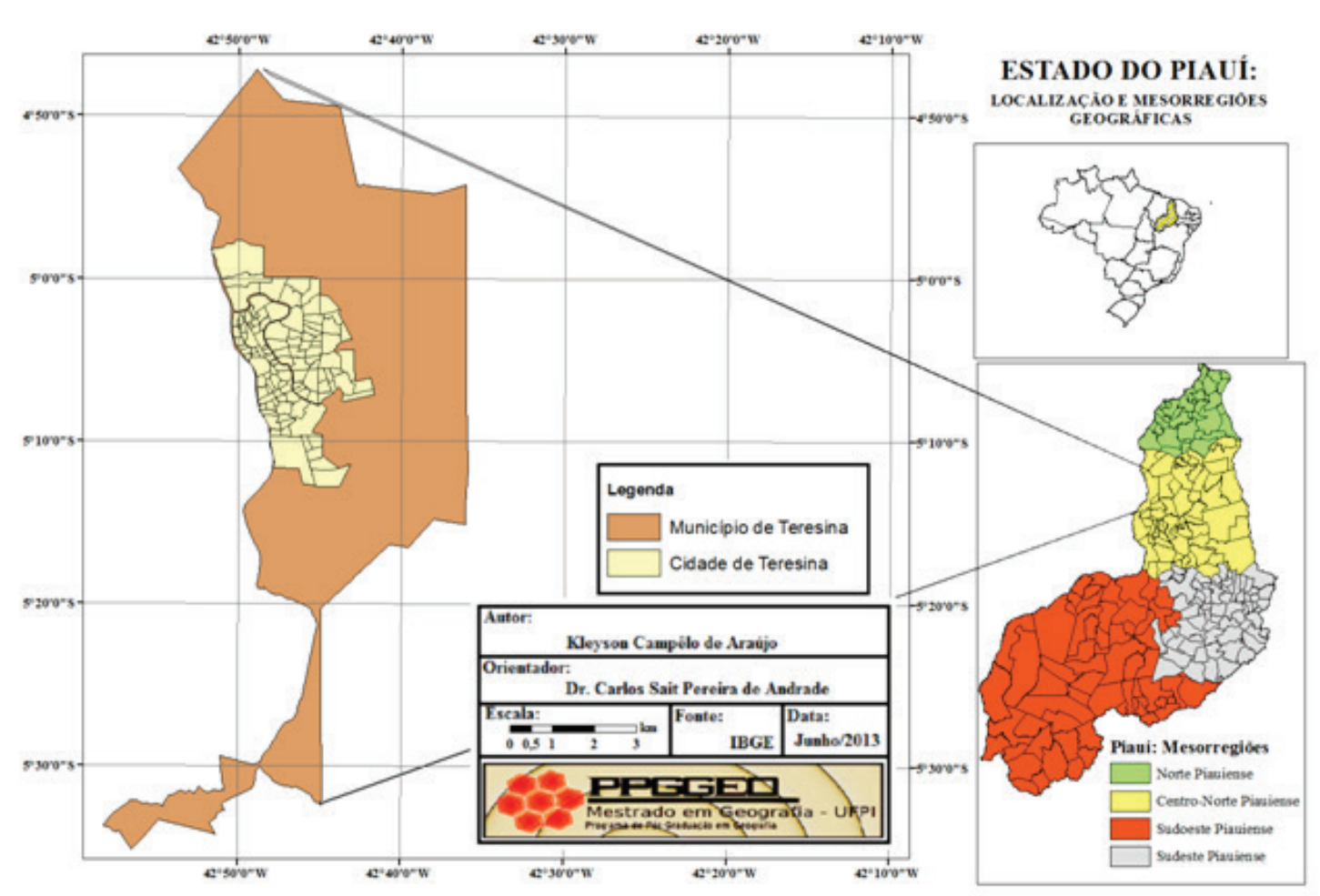

Fonte: Araújo, 2014. 
Nesse contexto, esta pesquisa visa suprir essa lacuna. Trata-se de um estudo do clima da cidade de Teresina, fundado na Teoria Geral dos Sistemas de Bertalanffy (2009) e Teoria e Clima Urbano de Monteiro (1976). Christofoletti (1979) escreve que os sistemas terrestres têm unidades ou elementos, relações, atributos, entrada (input) e saída (output). Os elementos constituem as partes que compóe o sistema, já as relações, a dependência interna que se expressam no fluxo, fruto das ligaçóes entre as unidades. Os atributos são qualidades que se conferem aos elementos. Esses variam de acordo com comprimento, volume, composiçáo e densidades dos fenômenos observados. Há entrada de energia e/ ou matéria no sistema que, após percorrerem o seu interior, são encaminhados para fora.

O clima urbano é um desses sistemas. Dada a sua configuração, os elementos que o compóe são de natureza complexa, impossíveis de serem compreendidos em sua plenitude. Ainda assim, é possível ter informaçóes do funcionamento do seu interior. Os Sistemas complexos são estudados pelos ruídos ou produtos gerados após percorrerem o interior do sistema. Os produtos originados fornecem informaçóes do funcionamento do sistema. Monteiro (1976) propóe o estudo do clima urbano através de três canais perceptivos: conforto térmico (subsistema termodinâmico), qualidade do ar (subsistema físico-químico) e impacto meteórico (subsistema hidrometeórico).

O conforto térmico foi o canal de percepção escolhido neste trabalho para demonstrar as derivaçóes antrópicas do clima teresinense e as ilhas de calor, os produtos. O principal objetivo, portanto, consiste em mapear ilhas de calor no espaço urbano teresinense. Entende-se ilha de calor como "uma área na qual a temperatura da superfície é mais elevada que as áreas circunvizinhas” (LOMBARDO, 1985, p. 24).

\section{PROCEDIMENTOS METODOLÓGICOS}

As cidades apresentam diferentes características e conjunturas arquitetônicas. O procedimento metodológico adotado deve ser capaz de contemplar a realidade investigada e suas singularidades. Amorim (2005a; 2005b; 2010), Lima (2011), Ugeda Jr. (2011) e Ortiz (2011) realizaram estudos de climatologia urbana embasados na Teoria Geral dos Sistemas e Teoria e Clima Urbano e embasam esta pesquisa.

Há três pontos comuns nesses estudos: (1) o referencial teórico, já explicitado; (2) a nomeação de pontos de mensuração fixos e móveis. Distribuíram os pontos de mensuração de acordo com a realidade investigada. Normalmente, os pontos fixos de medidas climatológicas localizavam-se na zona rural no entorno da cidade. Transectos móveis atravessavam a cidade nas direçóes norte-sul e leste-oeste, mensurando temperatura do ar e umidade relativa do ar. Nos transectos, os autores fixaram uma haste de madeira na lateral de um automóvel e na ponta da haste prendiam o sensor do termo-higrômetro. Nomearam o percurso que seria realizado contemplando espaços urbanos com realidades diferentes como, por exemplo, maior e menor adensamento, verticalização, áreas comerciais e residenciais. O segmento era dividido em distâncias precisas com uso de um odômetro e as coordenadas geográficas de cada intervalo eram devidamente anotadas. Cada dado coletado nos intervalos do segmento era correlacionado com as coordenadas geográficas; (3) 
utilizaram programas computacionais denominados de Sistema de Informação Geográfica (SIG) para relacionar as medidas climatológicas às coordenadas geográficas. O resultado foram cartas de isotermas e isoígras.

As mensurações de temperatura do ar atmosférico, umidade relativa do ar e velocidade dos ventos, presentes neste trabalho, foram realizadas na cidade de Teresina no mês de março de 2013. Para a análise dos resultados foram elaboradas cartas de isotermas e isoígras por meio do Software ArcGIS 10.1 de domínio da empresa ISRI. A ideia é visualizar a variação da temperatura do ar atmosférico nos diferentes pontos da cidade, identificando amplitudes térmicas urbano-rurais e ilhas de calor. Com intuito de inserir a realidade pesquisada no contexto dos sistemas atmosféricos regionais, foram utilizadas cartas sinóticas disponíveis na página virtual da Marinha do Brasil e as imagens coloridas dos satélites Goes-12 e Goes-13 do Centro de Previsão do Tempo e Estudos climáticos do Instituto Nacional de Pesquisas Espaciais.

O clima da cidade de Teresina é do tipo trópico-equatorial, com seis meses secos (MENDONÇA; DANNI-OLIVEIRA, 2007).O período chuvoso estende-se entre os meses de dezembro a maio e o seco de junho a novembro. A construção do climograma atendendo o parâmetro oficial mínimo de trinta anos evidenciou os meses de março e outubro como paradoxais do ponto de vista de normais climatológicas e conforto térmico (Gráfico 1). O mês de março é o mês de maior umidade relativa do ar e menores temperaturas do ar atmosférico. É também o mês mais chuvoso. Por outro lado, o mês de outubro apresenta as maiores temperaturas do ar e menor umidade relativa do ar, sendo o de menor índice pluviométrico. Com objetivo de demonstrar o comportamento climático da cidade de Teresina, optou-se por seis episódios no mês de março. $\mathrm{O}$ objetivo consiste, entre outras coisas, relacionar as características climáticas regionais à formação de ilhas de calor.

Gráfico1 - Teresina-PI: Clima tropical-equatorial (1977-2009)

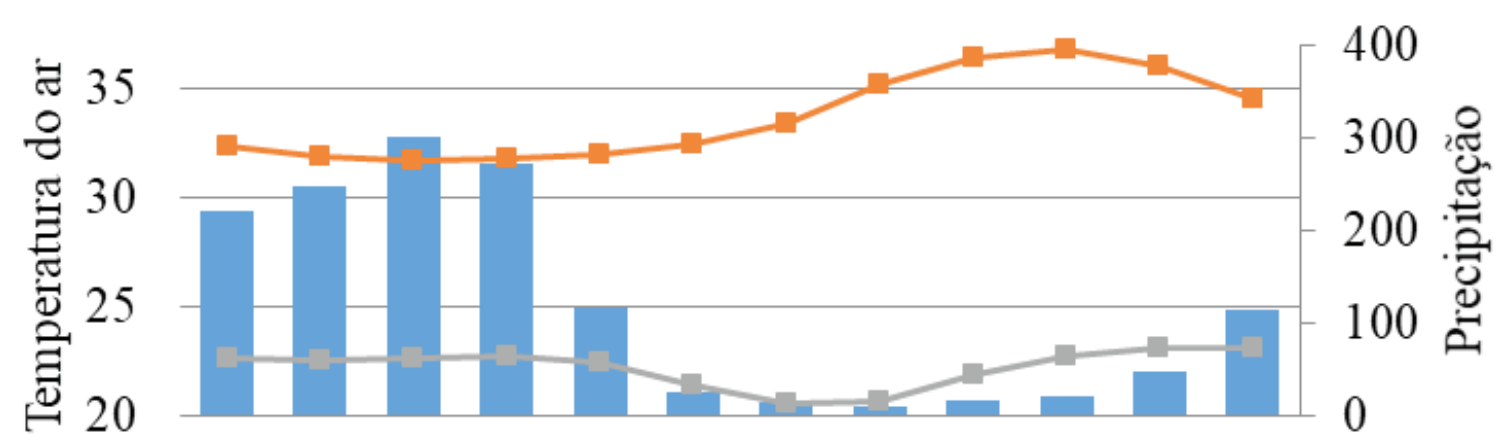

jan. fev. mar. abr.mai. jun. jul. ago. set. out. nov. dez.

Precipitação $(\mathrm{mm}) \rightarrow-$ Temp. Máx. $\left({ }^{\circ} \mathrm{C}\right) \longrightarrow-$ Temp. Min $\left({ }^{\circ} \mathrm{C}\right)$

Fonte: Araújo, 2014. 
A escolha dos pontos de mensuraçôes climatológicas foi alicerçada em análise cartográfica e reconhecimento in loco. A carta topográfica DSG do município, em escala 1:100.000, foi combinada com o mapa em escala maior, 1:25.000, de uso e ocupaçáo de terras da cidade de Teresina. Em campo, avaliaram-se áreas de expansão urbana horizontal e vertical, espaços de amenidades, áreas com maior e menor adensamento, avenidas com e sem arborização, o papel dos recursos hídricos na manutenção da temperatura, entre outros fatores. Três segmentos para a realização de transectos móveis foram traçados como resultados desse processo, conferindo um perfil radial. A Igreja Nossa Senhora do Amparo (INSA), considerada "Marco-Zero" da cidade e localizada no bairro Centro, foi escolhida como ponto de partida dos transectos. A direção dos segmentos nomeados foram centro-norte, centro-leste e centro-sul da cidade de Teresina. Os segmentos possuíam, em média, quinze quilômetros e foram divididos em intervalos de quinhentos metros. Munido de um Sistema de Posicionamento Global (GPS) e odômetro as coordenadas geográficas desses intervalos foram anotadas e tabuladas no Software Excel, de domínio da empresa Microsoft. As mensurações móveis de temperatura do ar e umidade relativa do ar foram realizadas nos intervalos dos segmentos, com média de trinta pontos por transecto, totalizando noventa.Sobre a realização dos transectos móveis, Amorim (2005a, p. 69) acrescenta uma particularidade:

A coleta de dados com veículo requer que o tempo gasto entre a medida do ponto inicial e no ponto final do itinerário não ultrapasse uma hora, com velocidade que deve variar entre 30 e $40 \mathrm{~km} / \mathrm{h}$. Esta metodologia foi adaptada, com base nos trabalhos de Oke e Maxwell (1975); Gomez e Garcia (1984); Johnson (1985); Pitton (1997).

O procedimento metodológico adotado difere de Amorim (2005a; 2005b; 2010), Lima (2011), Ugeda Jr (2011) e Ortiz (2011) em dois aspectos. Primeiro, há o perfil radial dos segmentos, isto é, centro-norte, centro-leste e centro-sul. A cidade de Teresina/ PI é conturbada com a cidade de Timon/MA em sua porção oeste. O recorte espacial náo incluiu esta cidade. Sendo assim, tornou-se inviável designar transectos entre os extremos rurais norte-sul e leste-oeste, com ponto de encontro nas áreas centrais. Outro aspecto diz respeito aos horários das mensuraçóes climatológicas, realizadas às 9 h, 15 h e 21 h e não apenas às $21 \mathrm{~h}$. Isso conferiu uma melhor compreensão do comportamento térmico da cidade e da variação diurno-noturna da temperatura, associada à umidade relativa do ar. A Organização Mundial de Meteorologia e Instituto Nacional de Meteorologia normatizam os horários das 9 h, 15 h e 21 h ( 12 h, 18 h e 00 h UTC) como padróes para captar estados atmosféricos diferenciados.

Para coleta de dados de temperatura do ar atmosférico e umidade relativa do ar nesses transectos móveis, foram utilizados termo-higrômetro digitais com sensores externos, fabricados pela empresa INCOTERM (Figura 2B). Uma haste de madeira foi acoplada a lateral de um veículo, onde se prendeu os senhores externos a 1,5m do solo (Figura 2A). 
Figura 2 -Fotografias dos instrumentos utilizados nas mensurações climatológicas
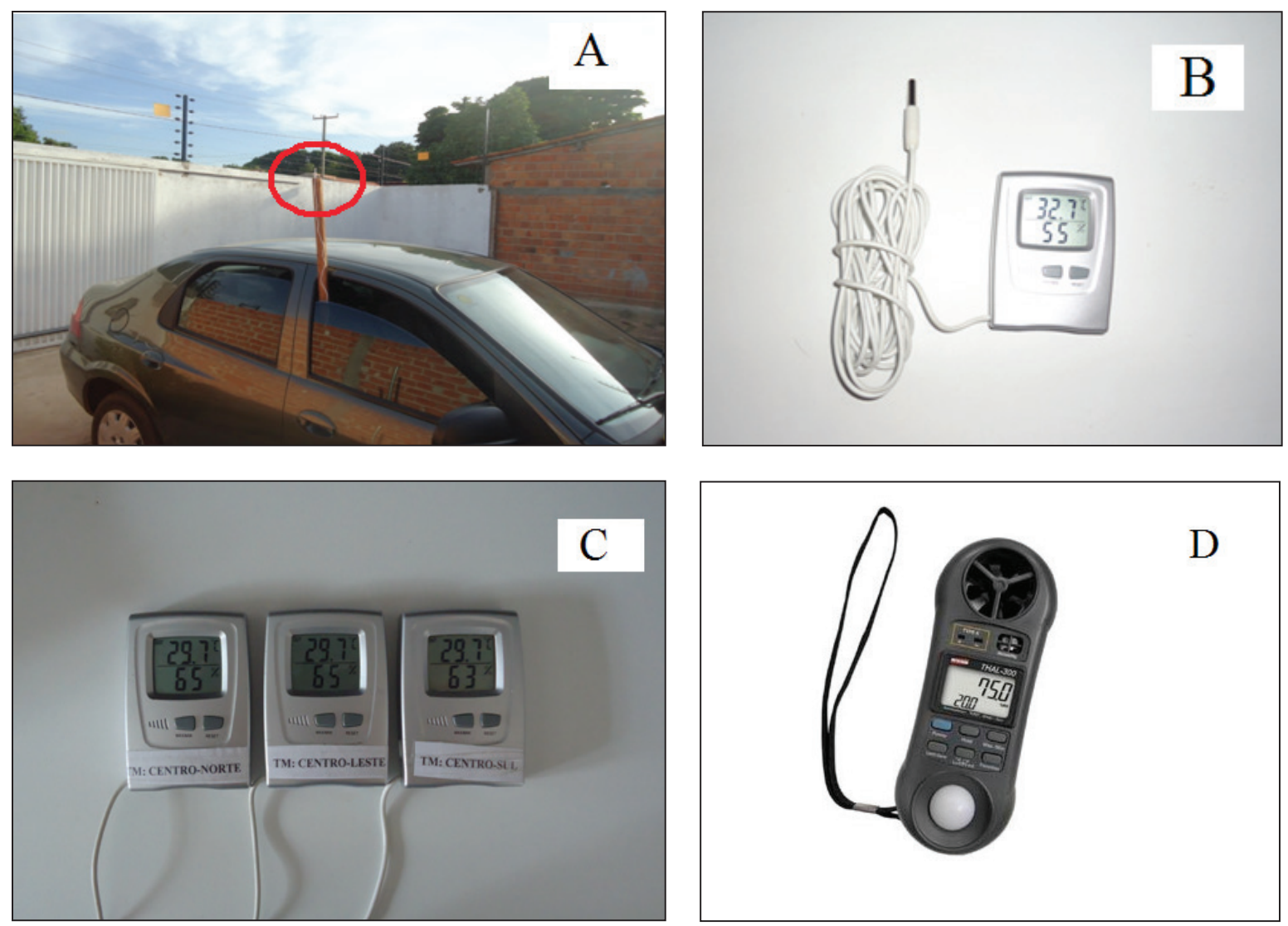

Fonte: Araújo, 2014.

As mensuraçóes climatológicas móveis somaram-se as em pontos fixos. Quatro pontos de medidas de temperatura do ar, umidade relativa do ar e velocidade dos ventos foram distribuídos pela cidade. Os critérios adotados para escolha dos pontos fixos foram os mesmos dos móveis, descritos anteriormente. Os pontos fixos localizavam-se na Igreja Nossa Senhora do Amparo e nos locais de chegada dos carros ao findar os transectos móveis, no limite urbano-rural nos sentidos norte, Leste e Sul. As mensuraçóes foram realizadas às $9 \mathrm{~h}, 15 \mathrm{~h}$ e $21 \mathrm{~h}$, simultaneamente, as saídas dos automóveis para a realização dos transectos.

As variaçóes no estado atmosférico num intervalo de tempo inferior a uma hora são pouco expressivas, mas possíveis de serem visualizadas. As medidas realizadas nos pontos fixos simultâneos entre si e com a saída dos automóveis para a realização dos transectos permitiram mapear as variaçóes atmosféricas no decorrer da realização dos percursos dos carros. Essas variaçóes foram analisadas no contexto regional através de imagens coloridas dos satélites Goes-12 e Goes-13 em intervalos de quinze em quinze minutos e, quando não possível, de trinta em trinta minutos. Essa conjuntura metodológica possibilitou concluir quais zonas da cidade se aquecem mais rápido, sobretudo entre $9 \mathrm{~h}$ e $10 \mathrm{~h}$, 
tendo por base a distribuição da umidade do ar e velocidade dos ventos. Cabe ressaltar que os pontos fixos, localizados nos limites urbano-rurais norte, Leste e Sul, estavam sob as mesmas condiçõoes ambientais, à sombra e distante de qualquer superfície e estrutura maximizadoras de calor.

Houve padronização dos termo-higrômetros utilizados para as mensuraçôes climatológicas fixas e móveis (Figura 2B). Antes da realizaçáo dos percursos, eles eram colocados lado a lado num mesmo ambiente para identificar disparidades das medidas de temperatura e umidade relativa do ar (Figura 2C). Nos dias pesquisados, os termo-higrômetros não apresentaram, entre si, medidas diferentes. As mensuraçóes da velocidade dos ventos foram realizadas por Termo-Higro-Anemômetro Luxímetro Digital portátil fabricado pela empresa Instrutherm, modelo THAL-300 (Figura 2D).

O ar comprometido pela urbanização deve ser comparado com ar livre. Monteiro (1990) recomenda que os dados colhidos pelo adentrar na cidade sejam comparados com os de estações meteorológicas oficiais, que usualmente são montadas em áreas não comprometidas pela urbanizaçáo - "ar livre". Em Teresina se têm duas estaçóes oficiais. A primeira é localizada no Aeroporto Petrônio Portella, bairro Aeroporto, e a segunda na Empresa Brasileira de Pesquisa em Agropecuária (EMPRAPA), no bairro Embrapa. Embora se tenha coletado dados nas duas estaçóes, a segunda enquadra-se melhor no que o autor chama de ar livre e seus dados seráo utilizados no relato dos episódios. $\mathrm{O}$ Aeroporto Petrônio Portella está localizado no espaço urbano teresinense, numa área de adensamento de construçóes horizontais. Acredita-se, assim, que uma comparação dos dados coletados em campo com esta estação não é viável.

As mensuraçôes móveis e fixas ocorreram nos dias 03, 05, 07, 10, 12 e 14 de março de 2013. Os seis dias úteis de pesquisa tiveram aferiçóes às $9 \mathrm{~h}, 15 \mathrm{~h}$ e $21 \mathrm{~h}$. Cada episódio somou 270 mensuraçôes móveis e doze fixas. Os dados coletados em campos foram tabulados no Microsoft Office Excel e espacializados através do ArcGIS 10.1, como mencionado anteriormente. Os resultados estão demonstrados em cartas de isoígras e isotermas que permitiram mapear o comportamento do campo térmico no decorrer de cada episódio.

Seguem as discussóes dos resultados coletados em campo, apresentados de forma episódica e através de cartas de isotermas e isoígras. Os títulos resumem o comportamento do campo térmico em destaque em cada episódio analisado.

\section{RESULTADOS E DISCUSSÃO \\ GEOMETRIA URBANA E CIRCULAÇÄO DE VEÍCULOS AUTOMOTIVOS NA PRODUÇÃO SE ESTRESSE TÉRMICO}

As imagens do satélite Goes-12 colorida explicitam Teresina, às 9 h do dia 03 de março de 2013, no centro do Vórtice Ciclônico de Alto Nível (VCAN), onde há subsidência de ar e o aumento da pressão, inibindo a formação de nuvens de chuvas (Figura 3A). Às 15 h, dá-se início a formação de uma Linha de Instabilidade (LI) ao longo do litoral do nortenordeste brasileiro (Figura 3B). A Zona de Convergência Intertropical (ZCIT) fortalece a LI 
e provoca seu deslocamento para o sul do estado do Piauí. Durante todo episódio, a ZCIT apenas influenciou no deslocamento da LI (Figura 3C).

Figura 3 - Imagem do GOES-12 colorida no episódio de 03 de março de 2013
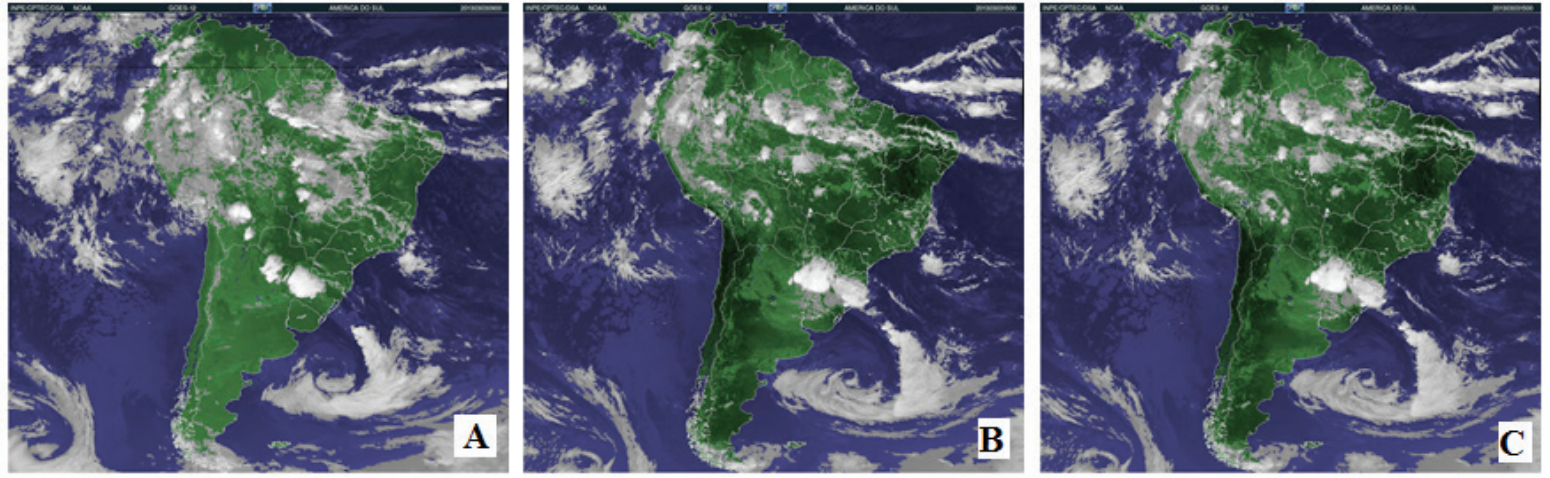

Fonte: INPE. Disponível em: <www.cptec.com.br>. Acesso em: 28 mar. 2013.

As temperaturas do ar atmosférico registradas às $9 \mathrm{~h}$ foram de $30,2{ }^{\circ} \mathrm{C}, 30,6{ }^{\circ} \mathrm{C}$ e $30{ }^{\circ} \mathrm{C}$ nos pontos fixos norte, leste e sul, respectivamente. No mesmo horário, o ponto fixo da Igreja Nossa do Amparo (INSA) registrava $2,6{ }^{\circ} \mathrm{C}$ a mais que a menor medida (Tabela 1).Ao final do transecto, constatou-se que houve um aumento maior da temperatura do ar no ponto fixo norte, $33,8^{\circ} \mathrm{C}$, contra $32,7{ }^{\circ} \mathrm{C}$ do leste e $32,6{ }^{\circ} \mathrm{C}$ do sul. Quais as causas associadas?

Às $9 \mathrm{~h}$ a zona norte de Teresina registrou menor umidade relativa do ar, entre $41 \%$ e 46 \%. Isso justifica o aquecimento do ar mais rápido, pois à medida que o sol radia a superfície, a condução é acelerada pela menor umidade do solo, consequentemente, a transmissão do calor para o ar sobre a superfície se dá de forma mais rápida. $\mathrm{O}$ contrário é verdadeiro, a zona Sul, com maior umidade, teve a menor temperatura entre os pontos fixos, $30^{\circ} \mathrm{C}$ (Tabela 1$)$.

Tabela 1 - Dados de temperatura do ar atmosférico (TAA), umidade relativa do ar (URA) e velocidades do vento (VV) dos Pontos Fixos - março de 2013

\begin{tabular}{c|c|c|c|c|c|c|c|c|c|c|c|c|c}
\multicolumn{9}{c|}{ CENTRO } & \multicolumn{3}{c|}{ NORTE } & \multicolumn{3}{c|}{ LESTE } & \multicolumn{3}{c}{ SUL } \\
\hline \multirow{3}{*}{ Dia } & Hora & $\begin{array}{c}\text { TAA } \\
\left({ }^{\circ} \mathrm{C}\right)\end{array}$ & $\begin{array}{c}\text { URA } \\
(\%)\end{array}$ & $\begin{array}{c}\text { W } \\
(\mathrm{m} / \mathrm{s})\end{array}$ & $\begin{array}{c}\text { TAA } \\
\left({ }^{\circ} \mathrm{C}\right)\end{array}$ & $\begin{array}{c}\text { URA } \\
(\%)\end{array}$ & $\begin{array}{c}\text { W } \\
(\mathrm{m} / \mathrm{s})\end{array}$ & $\begin{array}{c}\text { TAA } \\
\left({ }^{\circ} \mathrm{C}\right)\end{array}$ & $\begin{array}{c}\text { URA } \\
(\%)\end{array}$ & $\begin{array}{c}\text { W } \\
(\mathrm{m} / \mathrm{s})\end{array}$ & $\begin{array}{c}\text { TAA } \\
\left({ }^{\circ} \mathrm{C}\right)\end{array}$ & $\begin{array}{c}\text { URA } \\
(\%)\end{array}$ & $\begin{array}{c}\text { W } \\
(\mathrm{m} / \mathrm{s})\end{array}$ \\
\hline \multirow{6}{*}{$03 / 03$} & $9 \mathrm{~h}$ & 32,6 & 63 & 0,4 & 30,2 & 67 & 0,2 & 30,6 & 74 & 0,8 & 30 & 59 & 0,9 \\
& $15 \mathrm{~h}$ & 37,2 & 42 & 1,0 & 33 & 51 & 0,0 & 34,2 & 64 & 0,0 & 32,4 & 57 & 0,0 \\
& $21 \mathrm{~h}$ & 30,4 & 48 & 0,0 & 28,8 & 58 & 0,0 & 30,3 & 79 & 0,0 & 31,9 & 59 & 0,0 \\
\hline \multirow{5}{*}{$05 / 03$} & $9 \mathrm{~h}$ & 30,8 & 61 & 0,3 & 30 & 74 & 0,2 & 30,5 & 78 & 0,4 & 30,8 & 50 & 0,0 \\
& $15 \mathrm{~h}$ & 36,7 & 38 & 0,6 & 35,7 & 48 & 0,0 & 36 & 60 & 0,1 & 35,1 & 48 & 0,1 \\
& $21 \mathrm{~h}$ & 30,7 & 56 & 0,0 & 29,1 & 66 & 0,0 & 30,0 & 72 & 0,0 & 30,4 & 58 & 0,0 \\
\hline \multirow{5}{*}{$07 / 03$} & $9 \mathrm{~h}$ & 29,5 & 75 & 1,0 & 30 & 78 & 0,2 & 30,3 & 79 & 0,7 & 29,7 & 49 & 0,0 \\
& $15 \mathrm{~h}$ & 34,1 & 44 & 0,1 & 32,5 & 57 & 0,1 & 33,3 & 65 & 0,1 & 33,5 & 63 & 0,1 \\
& $21 \mathrm{~h}$ & 28,6 & 55 & 0,0 & 27,1 & 70 & 0,0 & 27,8 & 72 & 0,0 & 27,8 & 70 & 0,0 \\
\hline
\end{tabular}




\begin{tabular}{c|c|c|c|c|c|c|c|c|c|c|c|c|c}
\multicolumn{9}{c|}{ CENTRO } & \multicolumn{3}{c|}{ NORTE } & \multicolumn{3}{c|}{ LESTE } & \multicolumn{3}{c}{ SUL } \\
\hline \multirow{4}{*}{$10 / 03$} & $9 h$ & 32,0 & 62 & 0,2 & 30,5 & 75 & 0,1 & 30,7 & 72 & 0,7 & 29,7 & 71 & 0,0 \\
& $15 \mathrm{~h}$ & 38,6 & 52 & 0,8 & 35,6 & 51 & 0,3 & 34,7 & 55 & 0,9 & 35,1 & 73 & 0,2 \\
& $21 \mathrm{~h}$ & 33,1 & 50 & 0,0 & 31,3 & 60 & 0,0 & 30,1 & 62 & 0,0 & 30,2 & 69 & 0,0 \\
\hline \multirow{5}{*}{$12 / 03$} & $9 \mathrm{~h}$ & 32,6 & 45 & 0,2 & 30,7 & 76 & 0,3 & 30,6 & 69 & 1,0 & 30,3 & 58 & 0,7 \\
& $15 \mathrm{~h}$ & 36,8 & 48 & 0,3 & 35,5 & 57 & 0,0 & 36 & 50 & 0,3 & 36,1 & 66 & 0,0 \\
& $21 \mathrm{~h}$ & 30,7 & 60 & 0,3 & 29,7 & 67 & 0,2 & 30 & 63 & 0,4 & 28,5 & 69 & 0,3 \\
\hline \multirow{5}{*}{$14 / 03$} & $9 h$ & 31,2 & 65 & 0,1 & 31,2 & 78 & 0,2 & 29,3 & 71 & 0,6 & 29,4 & 72 & 0,1 \\
& $15 h$ & 36,6 & 55 & 0,2 & 35,8 & 62 & 1,0 & 34,8 & 72 & 0,3 & 34,9 & 59 & 0,0 \\
& $21 \mathrm{~h}$ & 30,1 & 43 & 0,0 & 29,8 & 69 & 0,4 & 29,5 & 64 & 0,8 & 29,0 & 73 & 0,9 \\
\hline
\end{tabular}

Fonte: Araújo (2014).

Os transectos radiais das $9 \mathrm{~h}$ revelaram quatro ilhas de calor, uma célula de ar fria e uma ilha de amenização térmica. Os bairros 0Poti Velho e Cidade Industrial, ao longo do segmento centro-norte, apresentaram ilhas de calor com magnitude máxima de $4,1^{\circ} \mathrm{C}$. O bairro Centro, na avenida Maranhão, revelou uma ilhota de calor de $3,1{ }^{\circ} \mathrm{C}$ se comparada a menor temperatura dos transectos. Neste trecho da avenida Maranhão há blocos de concreto sustentados por colunas no canteiro central que abriga os trilhos que culminam na Estação de Passageiros Engenheiro Alberto Tavares Silva, Shopping da Cidade. Isso favorece a maior retenção de calor, uma vez que o concreto possui grande difusividade térmica. Outro aspecto é que a construção dessa estrutura dificulta dispersão do calor para as camadas mais altas da atmosfera (Figura 4).

O trajeto centro-leste identificou uma ilha de calor com amplitude máxima de 3,3 ${ }^{\circ} \mathrm{C}$ no bairro São Cristóvão, no cruzamento das Avenidas João XXIII e Presidente Kennedy - Balão do São Cristóvão. Os bairros do entorno da ponte Juscelino Kubitschek possuem adensamento de condomínios verticalizados. Durante a realizaçáo desse trajeto, os bairros apresentaram uma célula de ar fria. As áreas verticalizadas fornecem bloqueio à radiação solar nas primeiras horas da manhá, gerando sombra e conforto térmico nos cânions urbanos. O mesmo não acontece ao meio dia, quando a radiação solar penetra nesses cânions e atingem seu fundo. Os edifícios, dessa feita, bloqueiam os ventos e dificultam a dispersão do calor. Esse resultado foi consubstanciado por Albuquerque (2012). 
Figura 4 - Mapa da distribuição espacial da temperatura do ar e umidade relativa do ar em Teresina - 03/03/2013 - $9 \mathrm{~h}$
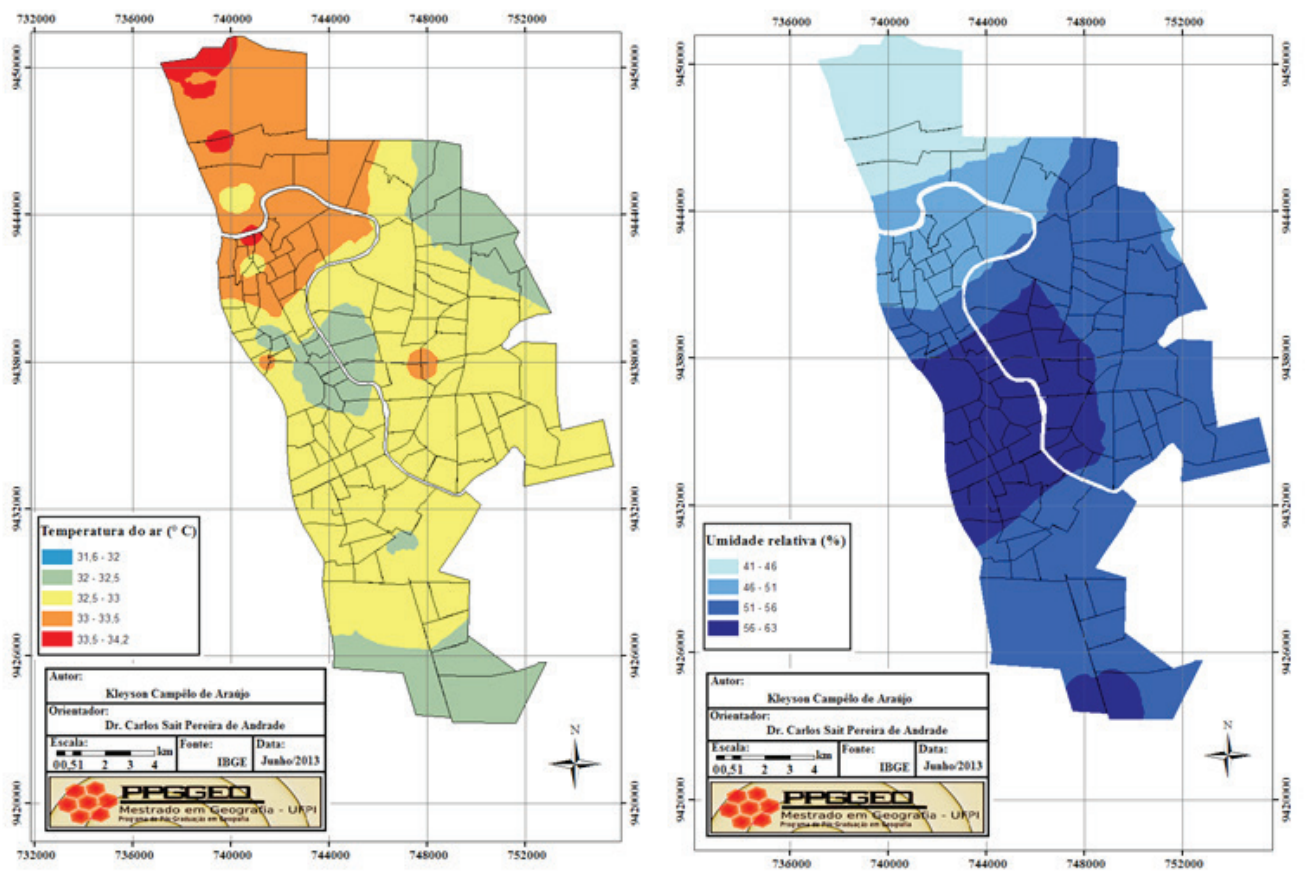

Fonte: Araújo (2014)

A redução da escala de análise ressalta particularidades do urbano que devem ser analisadas. O bairro Poti Velho encerra o primeiro perfil urbano no segmento centronorte, descrito anteriormente. Após a Ponte Dr. Mariano Castelo Branco, há áreas de campos abertos. As ilhas de calor e de amenização térmica coincidem com os núcleos de adensamento de casas, que se intercalam com vazios urbanos. Por outro lado, o estresse térmico nos bairros São Cristóvão e Centro está associado a grande circulação de veículos automotores, marcados pela bifurcação das Avenidas João XXIII/Presidente Kennedy e Miguel Rosa/Rui Barbosa, eixos de ligação nos sentidos Leste-Centro e Norte-Centro.

A importância dos corpos hídricos manifesta-se na formação de um ponto de amenização térmica no bairro Mafrense, entre as Lagoas do Alto Alegre e Nova Brasília. A condução do calor em superfícies líquidas é lenta, consequentemente, o ar sobre essas se aquece de igual forma. As lagoas são circundadas por vegetação nativa que fornece sombra contribui para formação de espaços de amenidades térmicas.

Os transectos das quinze horas registraram mudanças no campo termodinâmico da cidade de Teresina, mas com possíveis correlaçóes com os das nove horas. As temperaturas do ar vespertinas seguem tendência contrária às matutinas no percurso centro-norte. Se pela manhá a menor umidade relativa contribuiu para o aquecimento rápido do ar, a tarde ela é responsável por reduzir as temperaturas em tendência contrária, uma vez que sob essas condiçôes de umidade, o ar superficial aquece e esfria rapidamente. Além disso, é natural que o ar mais aquecido pela manhã suba por convecção. Por outro lado, a maior umidade relativa do ar, nos segmentos centro-leste e centro-sul, gera maior retençáo de calor pelo ar e, em decorrência, temperaturas mais elevadas. No transecto centro-sul identificaram-se 
duas ilhas de calor: Balão da Tabuleta (Avenidas Miguel Rosa/Getúlio Vargas/BR 316) e BR 316 na altura do bairro Santo Antônio. O Balão da Tabuleta possui fluxo intenso de carros e semáforo que forma congestionamento, que ocasiona concentração de poluentes e gases de efeito estufa como, por exemplo, o Dióxido de Carbono $\left(\mathrm{CO}_{2}\right)$.A concentração desses gases resulta em maior retenção de calor.

A BR-316, ainda no segmento centro-sul, é margeada pelos bairros Santo Antônio, Santa Cruz, Parque Jacinta e Parque Juliana. O trecho é caracterizado por um ambiente de grande adensamento de casas, pavimentação asfáltica, com redução de cobertura vegetal, entre outros fatores. $\mathrm{O}$ ambiente resultante dessa configuração gerou uma ilha de calor. Além disso, é uma área com grande oferta de serviços tais como troca de pneus, madeireiras, estofaria, entre outros. Os galpóes que abrigam essas empresas de serviços nas margens da BR-316 são cobertos com estruturas metálicas, onde a condução e liberação de calor são facilitadas.

Às 21 horas há um quadro térmico homogêneo. Uma grande célula de calor é formada no sentido do trajeto centro-sul de Teresina concomitante com as áreas mais úmidas. A zona norte mantém uma redução mais rápida de temperatura do ar com mínima de $25,6{ }^{\circ} \mathrm{C}$, ao passo que o centro da cidade registra máxima de $31,7{ }^{\circ} \mathrm{C}$ conferindo uma amplitude térmica de $6{ }^{\circ} \mathrm{C}$. No bairro Santa Rosa, já tratado anteriormente, houve redução de temperatura com predomínio de campos (Figura 5).

Figura 5 - Mapa da distribuição espacial da temperatura do ar e umidade relativa do ar em Teresina - 03 mar. $2013-21 \mathrm{~h}$
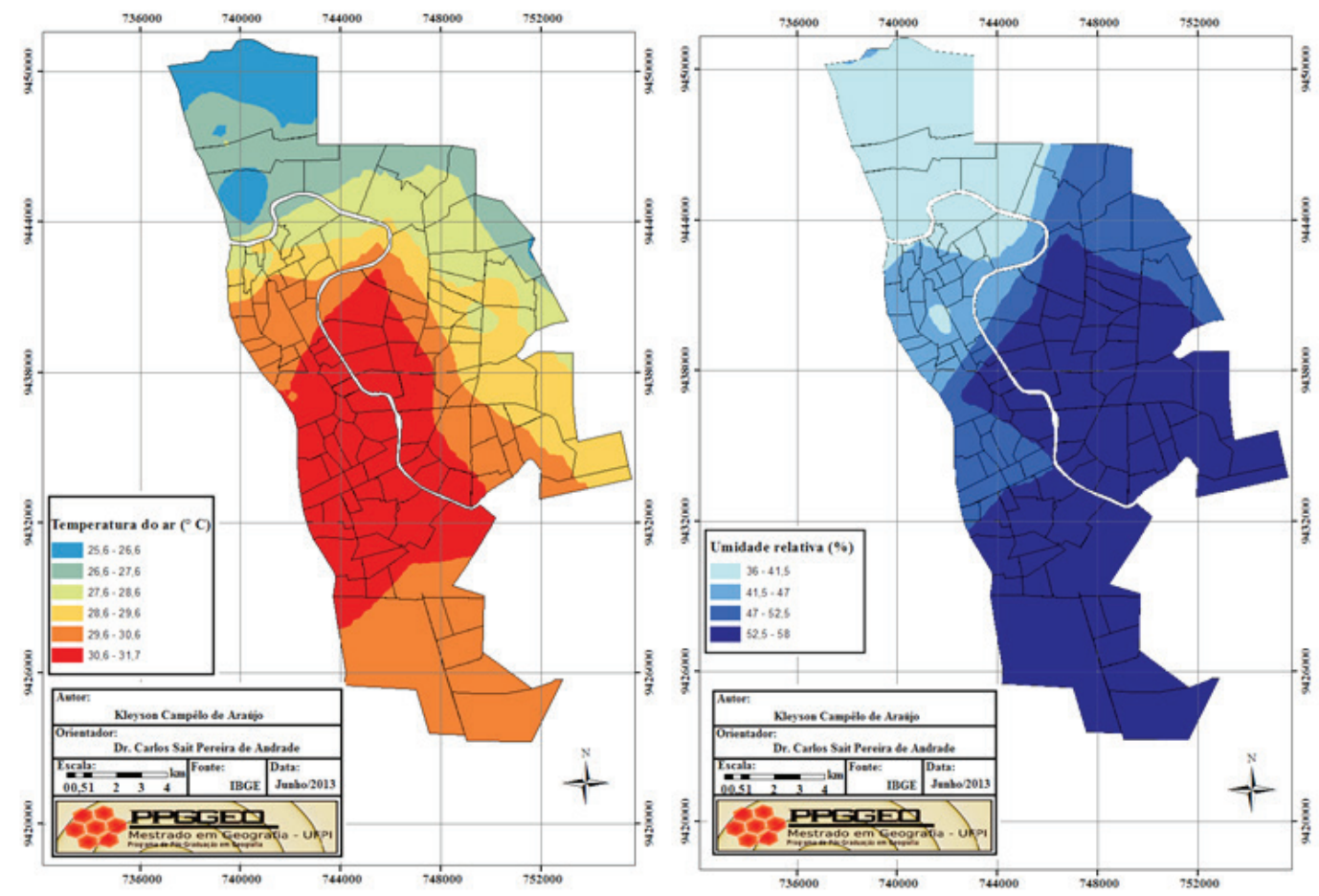

Fonte: Araújo (2014) 
De modo geral, os ventos mensurados nos pontos fixos não ultrapassaram a cota de $1,0 \mathrm{~m} / \mathrm{s}$. Às 21 horas, os ventos foram inexistentes, o que dificultou a dispersão do calor no bairro Centro e originou a célula. As maiores rajadas ocorreram pela manhá nos pontos fixos leste, $1,3 \mathrm{~m} / \mathrm{s}$, e à tarde no ponto fixo norte, $2,0 \mathrm{~m} / \mathrm{s}$. Isso justifica, de maneira mais veemente, o porquê dessas zonas estarem mais frias.

\section{A UMIDADE RELATIVA DO AR COMO RESPONSÁVEL PELA CONDUÇÃO E TRANSMISSÃO DO CALOR NO INTRAURBANO TERESINENSE}

A atmosfera piauiense comportou-se de maneira heterogênea durante o episódio do dia 05 de março de 2013. Às nove horas a região centro-norte piauiense estava sob a periferia do VCAN, que geralmente ocasiona chuvas (Figura 6A).Em Teresina, porém, a estação meteorológica EMBRAPA não registrou chuva em nenhum momento do dia, o que foi comprovado em campo. Durante o período vespertino, formou-se LI ao longo do litoral norte-nordeste brasileiro (Figura 6B). Entretanto, a posiçáo da Zona de Convergência Intertropical mais ao norte manteve a LI enfraquecida até o fim da tarde. No período noturno, o VCAN concorre com a LI sobre a atmosfera teresinense (Figura 6C).

Figura 6 - Imagem do GOES-12 colorida no episódio de 03 de março de 2013
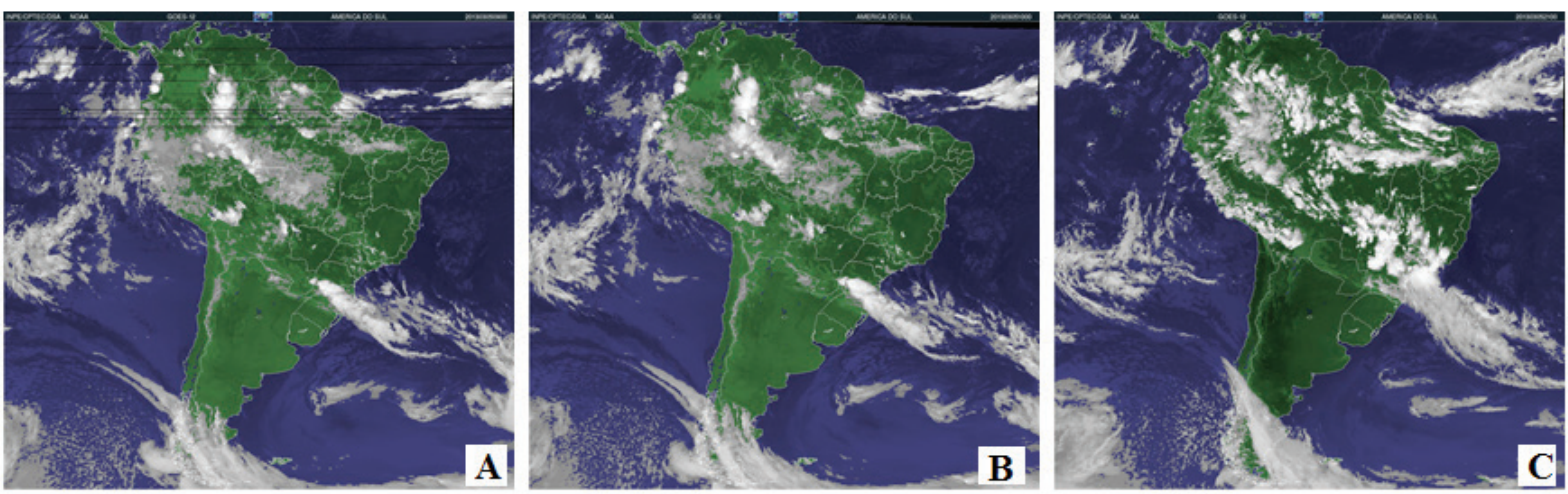

Fonte: INPE., 2013. Disponível em www.cptec.com.br. Acesso 28/03/2013.

Às nove horas, os termo-higrômetros instalados nos limites urbano-rurais registraram temperaturas do ar de $30{ }^{\circ} \mathrm{C}, 30,5^{\circ} \mathrm{C}$ e $30,8^{\circ} \mathrm{C}$ nos sentidos norte, leste e sul da cidade, respectivamente. Na Igreja Nossa Senhora do Amparo (INSA) a temperatura do ar era de 30,8 ${ }^{\circ} \mathrm{C}$ no mesmo horário (Tabela 1 ). A maior temperatura do ar no limite urbano -rural sul, às nove horas, condiz com a maior umidade relativa do ar. Quando em maior porcentagem, a umidade relativa do ar mantém maior regularidade térmica, pois o vapor d'água retém calor. Desse modo, as temperaturas não reduzem tanto durante a madrugada. Todavia, é interessante notar que, ao final da realização dos transectos da manhá, o segmento centro-norte já apresentava maiores temperaturas, quando comparadas as do centro-sul. $\mathrm{O}$ aquecimento mais rápido do ar sobre a superfície no segmento centro-norte 
justifica-se pela menor umidade. Como dito anteriormente, o solo seco favorece a condução do calor na superfície e consequente transmissão para baixa troposfera.

Os transectos das nove horas evidenciaram a presença de ilhas de calor nos bairros Poti Velho, Aeroporto e Cidade Industrial, no segmento centro-norte. Os bairros Poti Velho e Aeroporto margeiam a Av. Centenário e configuram um espaço de adensamento de casas residências de até dois pavimentos. Há apenas um edifício residencial ao longo da avenida, Condomínio Galileia. Trata-se de um ambiente de grande fluxo de veículos automotores e com ausência de arborização, com exceção de duas praças de pequena extensão, Praça Engenheiro José de Almeida Neto (Itaperú) e Poti, e do canteiro central da avenida, com árvores de pequeno médio e com copas que produzem pouca sombra. Já o bairro Cidade Industrial é formado por um núcleo de casas residenciais em meio a vazios urbanos, o que justificaria a formação de uma ilhota de calor com amplitude máxima $3,8^{\circ} \mathrm{C}$. Quanto ao bairro Poti Velho a amplitude sobre a mínima foi de $4,8{ }^{\circ} \mathrm{C}$.

A área central urbana encontrava-se mais fria do que as do extremo-rurais, nas mensuraçóes simultâneas das nove horas. As temperaturas do ar no ponto fixo da INSA e dos extremos - rurais apresentaram uma pequena diferença nesse horário, entre $30{ }^{\circ} \mathrm{C}$ e $30,8{ }^{\circ} \mathrm{C}$. Comprovou-se, no entanto, o papel da umidade relativa do ar na conduçáo e transmissão do calor pela cidade. Os percursos realizados pelos automóveis duraram em torno de quarenta minutos e, nesse intervalo de tempo, as zonas da cidade menos úmidas aqueceram o ar superficial mais rápido. $\mathrm{O}$ trajeto centro-norte, por exemplo, teve uma variação máxima de $4,8^{\circ} \mathrm{C}$ entre a menor medida, $30^{\circ} \mathrm{C}$ no ponto fixo às $9 \mathrm{~h}$, e as ilhas de calor de maior intensidade nos bairros já citados, com temperatura máxima de 34,8 ${ }^{\circ} \mathrm{C}$. Cabe ressaltar, os ventos de $0,3 \mathrm{~m} / \mathrm{s}$ e rajadas de $1,7 \mathrm{~m} / \mathrm{s}$ mensurados às nove horas na INSA que contribuíram para que as temperaturas estivessem amenas no centro da cidade.

Nas mensurações vespertinas houve semelhanças com o episódio anterior, isto é, áreas com menor umidade constituem-se como de perda rápida de calor para atmosfera e possuem temperaturas mais frias. A zona norte da cidade de Teresina é novamente exemplo. Uma segunda semelhança diz respeito a pontos de maior temperatura, próximas das Lagoas do Alto Alegre e Nova Brasília e Balão da Tabuleta. Este no segmento centro-sul e aquelas no centro-norte. Esses corpos hídricos de pequena extensão, em meio a um grande adensamento urbano e circulação de carros e motos, mostraram-se pouco expressivos em regular a temperatura do ar durante a tarde. A causa da ilha de calor no Balão da Tabuleta é a mesma do episódio anterior.

Há um fato novo a ser abordado. Houve o aumento das temperaturas do ar no final do segmento centro-sul. Como o episódio em questão se trata de um dia semanal útil, as indústrias no Polo Residencial e Industrial Sul estavam a "pleno vapor".Além disso, a BR-316 é, após os bairros Promorar e Parque Piauí, o único acesso aos bairros do centro-sul de Teresina e cidades do sul do estado do Piauí. O fluxo de caminhóes soma-se a automóveis particulares de moradores dos bairros Esplanada, Portal da Alegria, Teresina Sul, dentre outros. Maiores emissóes de $\mathrm{CO}_{2}$ resultam em maior absorção de calor. Ao final da tarde, há grande concentração de gases devido ao funcionamento das indústrias do Polo Residencial e Industrial Sul e fluxo de veículos automotores. 
Houve pancadas de chuvas no fim da tarde, por volta das $17 \mathrm{~h} 20 \mathrm{~min}$, nos pontos fixos nos extremos norte e Sul. Como consequência dessa chuva rápida, os extremos dos segmentos centro-norte e centro-sul registraram maior umidade relativa do ar. Às $21 \mathrm{~h}$, com as condiçóes de instabilidade atmosféricas, o comportamento térmico da cidade é homogêneo. Assim como no episódio anterior, há a formação de uma célula de calor no centro da urbe. A estação meteorológica Embrapa, localizada no bairro Embrapa, registrou temperatura máxima de $34,9^{\circ} \mathrm{C}$, após a chuva. Se por um lado, devido a maior umidade do ar, no bairro Embrapa as temperaturas quentes foram mantidas, no extremo setentrional da cidade, que se encontrava mais frio à tarde, manteve-se com menores temperaturas. Em síntese, a umidade relativa do ar manteve o comportamento térmico da tarde.

\section{TENDÊNCIA CLIMATOLÓGICA DA CIDADE DE TERESINA SOB A AÇÃO DO VCAN E A COMPLEXIDADE DAS ILHAS DE CALOR}

O VCAN esteve atuante durante todo o dia sobre a cidade de Teresina no episódio do dia 07 de março de 2013. Em termos de cobertura de nuvens e chuvas, porém, foi pouco expressiva. E estação EMBRAPA registrou $9,5 \mathrm{~mm}$ de chuvas, entre 00 e sete horas (UTC).Às nove horas o extremo norte manteve-se com maiores temperaturas do ar. Mais uma vez o comportamento térmico da urbe é definido pela umidade relativa do ar. Os pontos fixos no extremo norte, Leste e Sul da cidade marcaram, nessa ordem, $30{ }^{\circ} \mathrm{C}, 30,3$ ${ }^{\circ} \mathrm{C}$ e 29,7 ${ }^{\circ} \mathrm{C}$ (Tabela 1). As maiores temperaturas coincidem com as de maior umidade relativa do ar pelas mesmas razóes já expostas. Novamente, o bairro Poti Velho apresentou-se pontualmente mais quente, Ilha de calor com magnitude máxima de $3,5^{\circ} \mathrm{C}$.

No segmento centro-leste, os bairros de maior adensamento vertical, às margens do rio Poti, apresentaram temperaturas médias de $30,5^{\circ} \mathrm{C}, 3,2^{\circ} \mathrm{C}$ acima da mínima registra$\mathrm{da}$ em todos os transectos. A umidade relativa do ar registrada nesses pontos foi em torno de $65 \%$, em média. Sendo assim, justifica-se a menor redução de temperatura durante as primeiras horas do dia. $\mathrm{O}$ vapor d'água na atmosfera atuou como regulador térmico. Houve a formação de uma celular de calor sobre o bairro Vale Quem Tem, no final do transecto centro-leste. Embora possua altitudes na casa dos $130 \mathrm{~m}$, mostrou-se mais quente. A menor umidade relativa do ar nessa altura do transecto, em relação ao entorno, foi responsável por facilitar a condução e transmissão do calor para o ar superficial.

Durante as mensuraçôes climatológicas dos transectos da tarde, as temperaturas mantiveram-se maiores nos bairros Frei Serafim, Ilhotas, Por Enquanto, Jóquei Clube e dos Noivos. Isso ocorre porque após o zênite, o sol incide nas paredes e no fundo dos cânions, comuns a áreas com grande adensamento de verticalização. Em decorrência, registraramse temperaturas de $1,2{ }^{\circ} \mathrm{C}$ acima da média de todas as medidas dos transectos e 2,8 ${ }^{\circ} \mathrm{C}$ de amplitude máxima. No segmento centro-sul, na altura do bairro Santo Antonio, mapeou-se uma ilha de calor de $0,8{ }^{\circ} \mathrm{C}$ e $2,4^{\circ} \mathrm{C}$ tendo os mesmos referenciais anteriores.

O transecto centro-norte à tarde evidenciou uma ilha de calor e uma célula de calor. A avenida Maranhão, nas proximidades do Shopping da Cidade, novamente mostrouse mais quente, pelas mesmas razóes descritas anteriormente. Dessa feita, $3^{\circ} \mathrm{C}$ e $1,5^{\circ} \mathrm{C}$ 
sobre as medidas mínima e média de todos os transectos, respectivamente. Uma célula de calor foi formada sobre os bairros Poti Velho e Mafrense. Isso prova que as Lagoas Alto Alegre e Nova Brasília não conseguem suprir a ausência de umidade do ar, regular a temperatura do ar e criar espaços de amenidades (Figura 7).

Há a formação de uma célula de calor no segmento centro-sul teresinense com temperatura do ar, entre $29,7^{\circ} \mathrm{C}$ e $30,5^{\circ} \mathrm{C}$ no período noturno, confirmando essa tendência sob a ação do VCAN, com ausência da atuação da ZCIT e LI do Norte-Nordeste brasileiro (Figura 7).O centro da cidade, com ausência de ventos, mostra-se mais quente que os limites urbano-rurais. Nas mensuraçóes das $21 \mathrm{~h}$ em particular, houve uma amplitude máxima, entre o rural e urbano, de 5,8 ${ }^{\circ} \mathrm{C}$. $\mathrm{O}$ trajeto centro-norte, dada a menor umidade do ar, mostrou menores temperaturas em relação aos outros transectos.

As ilhas de calor podem gerar brisas. $\mathrm{O}$ ar quente é de baixa pressão e o ar frio de alta pressão. Um ponto com maior temperatura sobre a superfície gera uma pequena célula de baixa pressão atraindo o ar em volta, o que ajuda a dispersar o calor local. No segmento centro-sul, na altura do bairro Santo Antônio, há um exemplo. Durante o período da tarde, formou-se uma ilha de calor, mas à noite o mesmo espaço constituía-se como ilha de amenidade térmica. Se reduzida da temperatura mais alta, entre os transectos, seria $2,7{ }^{\circ} \mathrm{C}$ mais amena (Figura 7). O Sistema Clima Urbano é de natureza complexa e seus produtos sequem igual tendência. $\mathrm{O}$ exemplo citado prova que as ilhas de calor, ao criar condiçóes para formação de brisas, podem ser responsáveis por criar ilhas de amenidade térmica.

Figura 7 - Mapa da distribuição espacial da temperatura do ar em Teresina do 07/03/2013 - às 15 h (esquerda) e 21 h (direita)
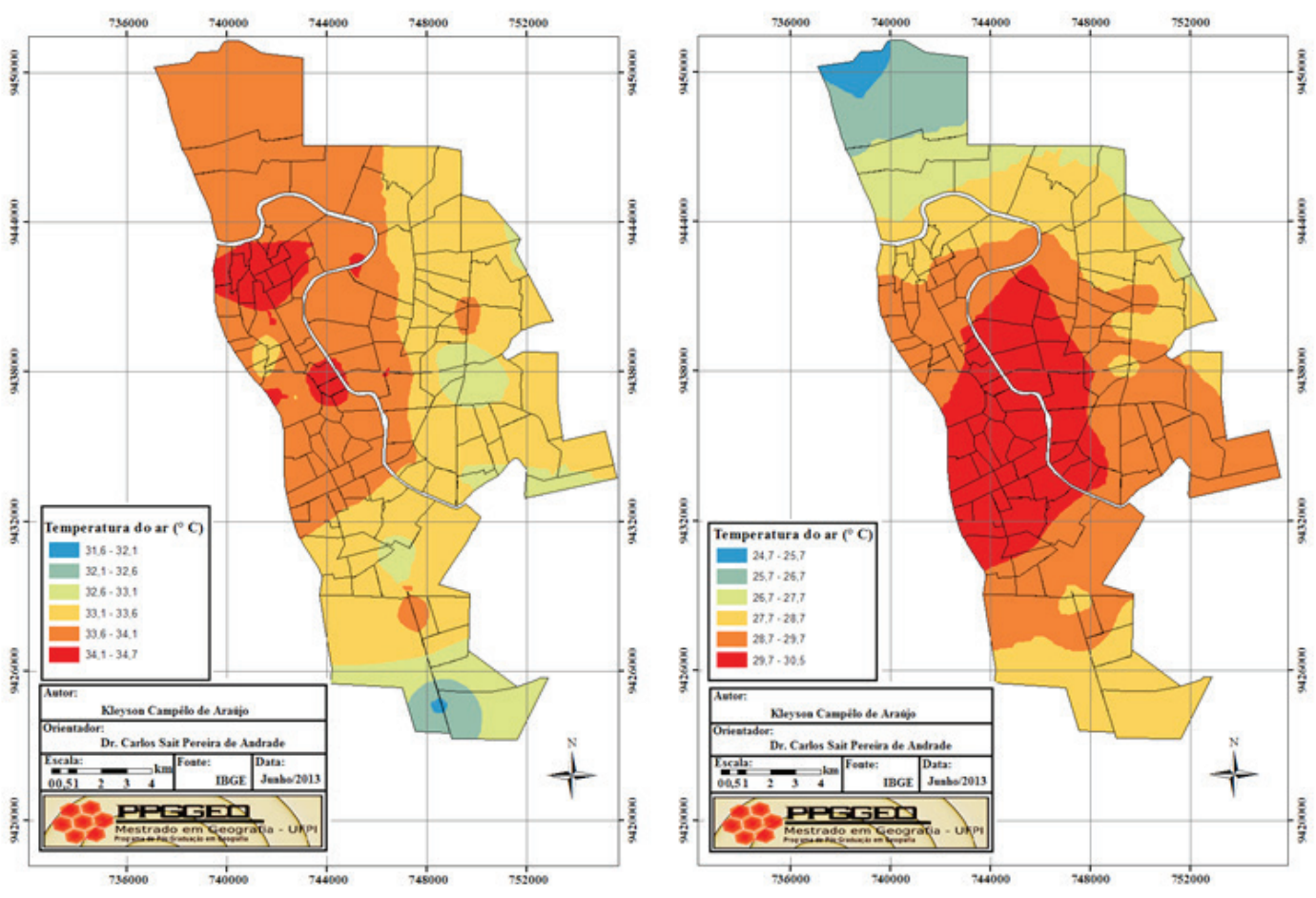

Fonte: Araújo, 2014 


\section{DERIVAÇÓES MICRO E MESOCLIMÁTICA NO ESPAÇO URBANO TERESINENSE COMO RESULTADO DA ESTABILIDADE ATMOSFÉRICA}

As condições atmosféricas nas primeiras horas da manhã eram favoráveis ao mapeamento de ilhas de calor na cidade de Teresina no episódio do dia 10 de março de 2013. A Estabilidade e céu limpo caracterizavam a atmosfera da urbe. À tarde, houve uma redução significativa da umidade relativa do ar de maneira inversamente proporcional ao aumento da temperatura. Durante a noite, segundo imagens coloridas do satélite GOES-12, há uma Linha de Instabilidade no centro-norte piauiense, dificultando o mapeamento dessas ilhas. É nesse episódio que as variações no campo higrométrico foram mais atuantes. O período vespertino, por exemplo, apresentou os menores valores de umidade relativa, entre $37 \%$ e $47 \%$ nas mensuraçóes realizadas na sazonalidade de março de 2013.

O segmento centro-norte destacou-se no que concerne a formaçáo de ilhas de calor e amenidade térmica. O bairro Poti Velho manteve a tendência à formação de ilhas de calor. Desta vez, com amplitude sobre a mínima de $2,7^{\circ} \mathrm{C}$. Um fato novo associa-se a formação de ilha de estresse térmico no bairro Aeroporto, $2,6^{\circ} \mathrm{C}$ de magnitude máxima. Como abordado na análise do episódio do dia 05 de março de 2013, os bairros Poti Velho e Aeroporto margeiam a avenida Centenário. É um espaço de grande adensamento de casas e com ausência de arborização. Nessa avenida ocorre um intenso fluxo de veículos automotores, pois ela é um importante elo entre os bairros da zona norte e centro da cidade. A avenida Maranhão, nas proximidades do Shopping da Cidade, evidenciou mais uma vez uma ilha de calor, com temperatura do ar $1,7^{\circ} \mathrm{C}$ mais quente do que os pontos do entorno e $2,7^{\circ} \mathrm{C}$ sobre a menor medida dentre os transectos.

$\mathrm{O}$ transecto centro-norte foi dividido em dois perfis intraurbanos. As ilhas de amenidade térmicas podem ser descritas a partir desses. No primeiro perfil, entre o Centro e a ponte Dr. Mariano Castelo, houve duas ilhas de amenidade térmica: na avenida Santos Dumont, margeada pelos bairros Pirajá e Vila Operária, e na avenida Centenário, nas proximidades das Lagoas Alto Alegre e Nova Brasília. A avenida Santos Dumont conta com arborização com copas fechadas. Durante as primeiras horas da manhã fornece sombra e impedem que a radiaçáo solar atinja o solo. O contrário é verdadeiro, as copas fechadas impedem a liberação do calor para as camadas mais altas da atmosfera. Silva (2009) provou que as copas fechadas da avenida Santos Dumont dificultam a dispersão do calor. Isso justifica as temperaturas do ar mais altas nessa avenida durante as mensurações da tarde.

Intercalou-se ilhas de frescor, célula de calor e célula fria no segundo perfil intraurbano, posterior a ponte Dr. Mariano Castelo. Isso se dá porque esse perfil constitui-se com áreas de vegetação nativa, campos abertos e conjuntos habitacionais isolados. As áreas mais quentes e frias coincidem, respectivamente, com as áreas de adensamento urbano e vazios demográficos. Entre os episódios analisados até aqui, é a primeira vez que o extremo urbano-rural norte apresentou uma menor diferença de umidade relativa do ar em relação aos outros extremos da cidade. Isso retardou o aquecimento do ar sobre a superfície, ocasionando menores temperaturas no final desse transecto. 
No segmento centro-sul, a BR-316 novamente evidenciou uma ilha calor na altura dos bairros Santo Antônio e Parque Jacinta, com amplitude máxima de $3,2{ }^{\circ} \mathrm{C}$ e $1,1{ }^{\circ} \mathrm{C}$ mais quente que o entorno. A mensuraçáo no ponto fixo sul, às nove horas, mostrou ausência de ventos, o que justificaria uma maior intensidade dessa ilha de calor (Tabela 1). Um aspecto relevante refere-se a celular fria que antecede a ilha de estresse térmico. A maior umidade relativa do ar dessa área desacelerou a conduçáo do calor e sua transmissão para o ar no período matutino. Nas mensurações da tarde, as temperaturas mais altas ainda persistiam nesse ponto da BR-316.

Os dados coletados nas mensurações da tarde mostraram mudanças significativas no campo higrométrico da cidade. Em decorrência, o campo térmico também sofreu alterações. Os bairros do primeiro perfil intraurbano do transecto centro-norte registram as maiores temperaturas. Mapearam-se duas ilhas de calor sobre a avenida Centenário, bairro Aeroporto, pelas mesmas razóes já discutidas. Cabe ressaltar que as menores temperaturas nos extremos urbano-rurais devem a circulação de ar mais atuante. Registraram-se rajadas de $1 \mathrm{~m} / \mathrm{s}, 2,1 \mathrm{~m} / \mathrm{s}$ e $1,5 \mathrm{~m} / \mathrm{s}$, sequencialmente, nos pontos fixos norte, leste e sul.

Às 21 horas, sob ação da LI do N-NE brasileiro, seguiu-se a tendência de formaçáo de uma célula de calor na porçáo centro-sul da cidade, condizente com a maior umidade relativa do ar. A amplitude máxima de temperatura entre essa célula e o limite urbano-rural foi de $4,7^{\circ} \mathrm{C}$. Em estabilidade atmosférica, a umidade relativa do ar tende a diminuir de forma inversamente proporcional ao aumento da temperatura do ar na cidade de Teresina.

\section{TENDÊNCIAS MICROCLIMÁTICAS NO INTRAURBANO TERESINENSE NA SAZONALIDADE DE MARÇO DE 2013}

O episódio do dia 12 de março de 2013 mostrou similitude com o anterior quanto às condiçóes favoráveis ao mapeamento de ilhas de calor. A ZCIT, LI e VCAN não atuaram sobre o centro-norte piauiense no período diurno. Às 21 horas o céu ficou parcialmente coberto, devido à localização sob a zona periférica do VCAN. Não houve chuva, porém, segundo a estação EMBRAPA e observação em campo.

Algumas condições mapeadas anteriormente apresentam-se como padrão, nas mensuraçóes da manhã. (1) O extremo urbano-rural norte, em menor umidade, tem conduçáo do calor acelerada e mostra maiores temperaturas que os extremos Leste e Sul da cidade; (2) No segmento centro-norte, a Avenidas Maranhão, perto do Shopping da Cidade, e Centenário, na altura das Lagoas do Alto Alegre e Nova Brasília, mostraramse mais quentes, $2,7^{\circ} \mathrm{C}$ sobre a temperatura mínima registrada nos transectos. (3) No segmento centro-sul, a BR-316, bairro Santo Antônio, consolida-se como propensa a formação de ilha de calor. Desta feita, $\operatorname{com} 2,4{ }^{\circ} \mathrm{C}$ de magnitude máxima, e; (4) No segmento centro-leste, as temperaturas estavam $2,7^{\circ} \mathrm{C}$ acima da mínima. Isso se deve aos edifícios que margeiam a avenida Frei Serafim.

Ainda pela manhã, os extremos dos transectos centro-norte e centro-leste estavam com menor umidade relativa do ar que o centro-sul. Entretanto, o centro-leste possuía menores 
temperaturas. Os ventos de $1,0 \mathrm{~m} / \mathrm{s}$ e rajadas de $2,4 \mathrm{~m} / \mathrm{s}$ foram determinantes nisso (Tabela 1). As maiores altitudes, sobretudo a partir do bairro Primavera Leste, atuaram de maneira mais incisiva na redução da temperatura do ar.

À tarde, a perda de calor por convecção para alta troposfera ocorreu mais rápida nos extremos urbanos norte e Leste devido a menor umidade relativa do ar. No final do Trajeto Sul, as maiores umidades dificultaram a dispersão do calor, gerando desconforto térmico. Notadamente, devido à ausência de ventos, a área central de Teresina permaneceu mais quente, com amplitude térmica máxima de $5,3{ }^{\circ} \mathrm{C}$.

As últimas mensurações do dia confirmaram que sob atuação dos VCAN e LI forma-se uma célula de calor no sentido centro-sul da cidade de Teresina, coincidindo com a maior umidade. Essa célula apresentou amplitude máxima de $2,6{ }^{\circ} \mathrm{C}$. No segundo perfil intraurbano do segmento centro-norte, as maiores e menores temperaturas do ar intercalaram-se, novamente, com os núcleos de adensamento e vazios urbanos.

\section{AS DERIVAÇÓES CLIMÁTICAS INTRAURNAS ASSOCIADAS À CIRCULAÇÃO DE VEÍCULOS AUTOMOTORES}

A imagem do satélite GOES-12 colorida deixa evidente a ação de um Complexo Convectivo de Mesoescala (CCM) sobre a atmosfera piauiense dia 14 de março de 2013 (Figura 8A).Forma-se na fronteira entre o Piauí e Ceará, pela manhá, e desloca-se para Teresina no período da tarde, onde ocorre sua dissipaçáo (Figura 8B). Uma vez que a dissipaçáo ocorreu antes de chegar à cidade de Teresina, não ocorreu precipitação, mas sim cobertura parcial do céu nas mensurações vespertinas. À noite, há a formação de LI no centro-norte do estado.

\section{FIGURA 8. DISSIPAÇÁO DE UM COMPLEXO CONVECTIVO DE MESOESCALA}
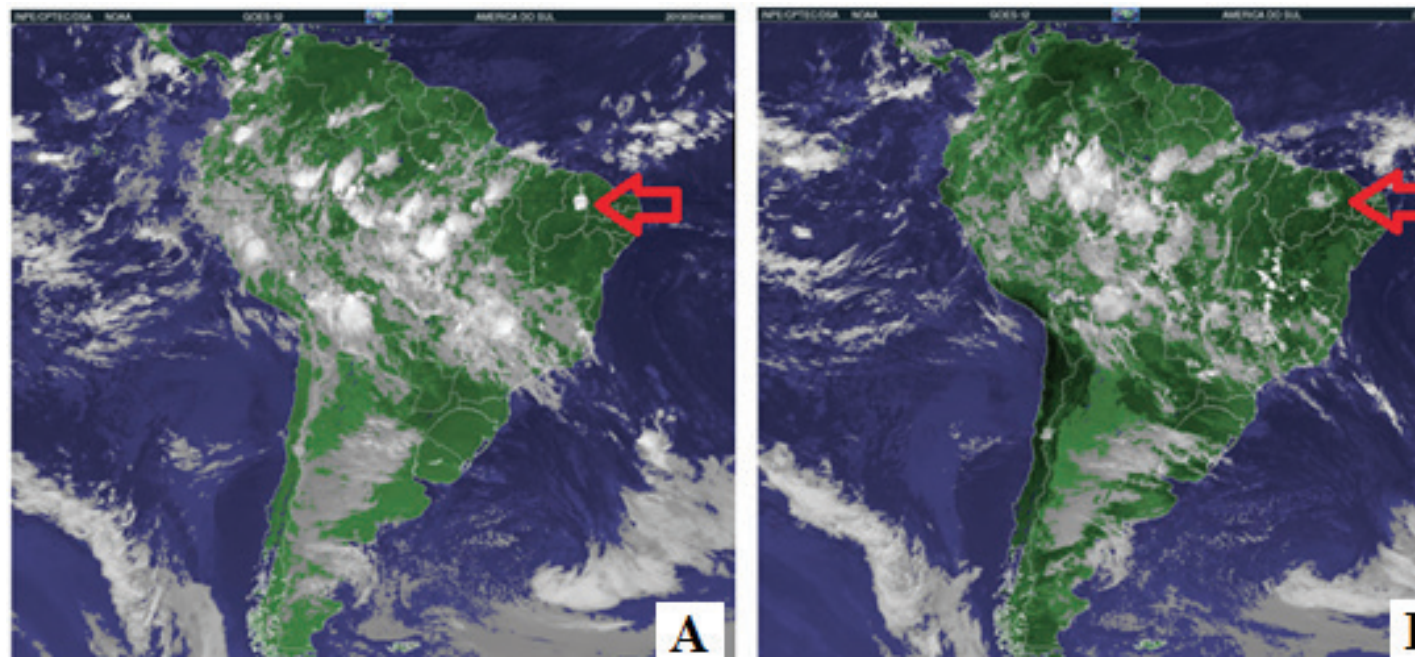

Fonte: INPE, 2013. Disponível em: www.cptec.com.br. Acesso 28/03/2013. 
As mensurações realizadas às $9 \mathrm{~h}$ nos pontos fixos INSA, norte, Leste e Sul expressam as temperaturas de $31,2^{\circ} \mathrm{C}, 31,2{ }^{\circ} \mathrm{C}, 29,3{ }^{\circ} \mathrm{C}$ e $29,4^{\circ} \mathrm{C}$, respectivamente (Tabela 1 ). O ponto fixo da INSA registrou a mesma temperatura do ar do Norte. As razóes estão associadas a menor umidade do ar no segmento centro-norte, por diversas vezes aqui explanada. Mapeou-se uma ilhota de calor no bairro Poti Velho, com magnitude máxima de $2,4^{\circ} \mathrm{C}$. O segmento centro-sul, na altura do bairro Santo Antonio, novamente mostrava-se mais quente, com $2,3^{\circ} \mathrm{C}$ acima da mínima entre os transectos da manhá. Outra ilha evidenciou-se no Baláo da Tabuleta, $3,1^{\circ} \mathrm{C}$ sobre a menor temperatura.

Um fato novo diz respeito às baixas temperaturas no centro da cidade. Isso ocorreu devido a uma chuva passageira nas primeiras horas da manhá. Em campo, observou-se o solo úmido no entorno da INSA, que dificultou a conduçáo do calor e sua consequente transmissão para a atmosfera. Ventos em torno de $1,0 \mathrm{~m} / \mathrm{s}$ e rajadas de $2,0 \mathrm{~m} / \mathrm{s}$ foram responsáveis pelas menores temperaturas na zona leste, expressas numa célula fria. Pela primeira vez, nas proximidades do conjunto Verde Lar, ainda no extremo leste, houve a formaçáo de uma ilha de calor de magnitude máxima de 2,6 ${ }^{\circ} \mathrm{C}$. Esta área se localiza em um vale, onde a expansão urbana tem se materializado através de pavimentação asfáltica e construçáo de conjuntos habitacionais horizontais. $\mathrm{Na}$ zona sul, o ponto fixo configurou-se como ilha de amenização térmica.

Na parte da tarde, o campo termodinâmico da cidade sofreu mudanças expressivas. O bairro Centro, na direçáo sul, aparece com o ar local mais aquecido, com destaque para o Baláo da Tabuleta e o cruzamento das Avenidas Valter Alencar e Miguel Rosa. Durante os dias semanais úteis é comum formar congestionamento nestes pontos o que justificaria magnitude máxima de $2,8{ }^{\circ} \mathrm{C}$ para a primeira ilha de calor e de $3,2{ }^{\circ} \mathrm{C}$ para a segunda. Ainda no sentido meridional, na BR-316, na altura do bairro Santo Antônio e Parque Jacinta, houve ilha de calor com temperatura de $3,4^{\circ} \mathrm{C}$ sobre a mínima registrada pelos transectos. A temperatura do ar sobre a avenida Joáo XXIII no cruzamento com a Presidente Kennedy, no segmento centro-leste, esteve $3{ }^{\circ} \mathrm{C}$ acima da mínima e $1,0^{\circ} \mathrm{C}$ a mais dos pontos mensurados no entorno. No segmento centro-norte, formouse uma célula fria sobre os bairros Santa Rosa e Poti Velho como consequência da menor umidade que facilitou a perda de calor para atmosfera. Próximo a ponto Dr. Mariano Castelo Branco, onde a umidade foi mais expressiva, a temperatura aferida no ponto foi de $35,5^{\circ} \mathrm{C}, 1,7^{\circ} \mathrm{C}$ sobre a mínima.

Às 21 horas a tendência de formação de célula no centro sul foi visualizada. $\mathrm{O}$ espaço de alto status, porém, configura uma ilha de calor com magnitude máxima de $4,9^{\circ} \mathrm{C}$ e $1,4^{\circ} \mathrm{C}$ sobre os pontos do entorno. Os pontos fixos sul e leste estiveram mais frios, com ventos, em média, de $1,0 \mathrm{~m} / \mathrm{s}$ com rajadas máximas de 2,0 m/s, no Leste.

\section{CONSIDERAÇÓES FINAIS}

A análise dos resultados expressos nas cartas de isotermas e isoígras permitem concluir que o mapeamento de ilhas de calor no período noturno na cidade é inviável, pois sob 
atuação dos VCAN e LI forma-se uma célula de calor no sentido centro-sul da cidade de Teresina, impossibilitando mapear especificidades microclimáticas.

As aferiçóes climatológicas realizadas colocam o segmento centro-norte como o de menor umidade relativa do ar, em praticamente todos os episódios. Isso provocou o aquecimento mais rápido do ar sobre a superfície, entre a primeira e última medida realizada pelos transectos móveis. O contrário é verdadeiro. Os extremos urbanos com maior umidade relativa do ar mostraram-se mais frios, pois o solo mais úmido dificulta a conduçáo do calor, retardando o aquecimento do ar sobre a superfície.

A geometria urbana exercer papel importante no condicionamento de microclimas. Exemplifica-se essa afirmativa através dos resultados dos episódios dos dias 03 e 07 de março. A verticalização exerceu um papel importante, ao bloquear a radiação solar nas primeiras horas da manhã, criando espaço de amenidade. Por outro lado, após a insolação atingir o fundo do cânion, há tendência à formação de ilhas de calor.

O episódio do dia 10 de março demonstra a arborização como condicionante de ilhas de calor. Comprovou-se que árvores com copas próximas e fechadas retardam a transmissão do calor para as camadas mais altas da atmosfera, aumentando a temperatura local. Os gestores públicos municipais devem considerar as singularidades climáticas ao planejar arborizar a cidade. Árvores com copas afastadas e bem posicionadas permitem a circulação do ar, reduzindo o stress térmico. 


\section{REFERÊNCIAS BIBLIOGRÁFICAS}

ALBUQUERQUE, Marcos M. de. Relação entre uso e ocupação dos solos e variáveis climáticas: estudo em bairros da cidade de Teresina, Piauí. Dissertação (Mestrado em Desenvolvimento e Meio Ambiente), Universidade Federal do Piauí, Teresina, 2012.

AMORIM, M. Cristiane de C. T. Intensidade e formas de ilhas de calor urbana em Presidente Prudente (SP): episódios de inverno. Revista Geosul, Santa Catarina, v. 20, n. 39, pp. 6582, jan.-jun.2005a.

. Ilhas de Calor em Birigui (SP). Revista Brasileira de Climatologia, v. 1, n. 1, dez. 2005b.

; MINAKI, C. Clima urbano em Guararapes (SP): episódios de verão e de inverno. Geografia, Rio Claro, v. 32, n. 2, pp. 295-318, maio.-ago. 2007.

. Climatologia e gestão do espaço urbano. Revista Mercator, , dez. 2010, pp. 71-90. (Número especial)

ANDRADE, C. S. P de. A climatologia da cidade de Teresina - PI: as variantes topoclimáticas nos espaços livres. Tese.(Doutorado em Geografia), Universidade Federal de Pernambuco, Recife, 2009.

ARAÚJO, Kleyson Campêlo. Espaço Urbano e Climatologia: ilhas de calor em evidência na cidade de Teresina (PI). 2014. Dissertação (Mestrado em Geografia) - Programa de Pós-Graduação em Geografia. Universidade Federal do Piauí. Teresina, 2014.

BERTALANFFY, L.von. Teoria Geral dos Sistemas: fundamentos, desenvolvimento e aplicações. 4. ed. Rio de Janeiro: Vozes, 2009.

BRANCO, A. E. O desenho urbano e sua relação com o microclima: um estudo comparativo entre duas áreas centrais em Teresina - Piauí. Universidade de Pernambuco Dissertação. (Mestrado em Geografia), 2001.

CHRISTOFOLLETI, A. Definição e classificação dos sistemas. In: Análise dos sistemas em geografia. São Paulo: HUCITEC/EdUSP, 1979.

FEITOSA, Sônia M. ${ }^{a}$ R. Alterações climáticas em Teresina-PI decorrentes da urbanização e supressão de áreas verdes. Universidade Federal do Piauí, Dissertação (Mestrado em Desenvolvimento e Meio Ambiente), Teresina, 2010.

HABITAT. Planificación y diseño de uma movilidad urbana sostenible: orientaciones para políticas. Nova Iorque: ONU, 2013.

KALLAS, Luana Miranda E. Desenhando com o clima e a vegetação: um estudo de caso do loteamento HBB em Teresina (PI). Dissertação (Mestrado em Arquitetura e Urbanismo), Universidade de Brasília, Brasília, 2008.

LIMA, G. N. Características do clima de Nova Andradina. Dissertação. (Mestrado em Geografia) Universidade Estadual Paulista (UNESP), São Paulo, 2011. 
LOMBARDO, M. A. Ilhas de calor nas metrópoles: o exemplo de São Paulo. São Paulo: HUCITEC, 1985.

MENDONÇA, F; DANNI-OLIVEIRA, I. M. Climatologia: noções básicas e climas do Brasil. São Paulo: Oficina de Texto, 2007.

MONTEIRO, C. A. de F. Caracteres climáticos de Teresina in Plano de Desenvolvimento Local Integrado. Teresina: Conplan, 1969.

MONTEIRO, C. A. de F. Teoria e Clima Urbano. São Paulo: Instituto de Geografia da USP, 1976. (Série Teses e Monografias, n. 25)

Adentrar na cidade para tomar-lhe a temperatura. GEOSUL - Revista do Departamento de Geociência, n. 9, ano 5, 1. sem., pp. 61-79, 1990.

ORTIZ, F. F. O clima urbano de Cândido Mota: análise do perfil térmico e higrométrico em episódio de verão. Dissertação (Mestrado em Geografia), Universidade Estadual Paulista (UNESP), 2011.

SILVA, Caio Frederico e. Caminhos Bioclimáticos: desempenho ambiental de vias públicas na cidade de Teresina (PI). Dissertação (Mestrado em Arquitetura e Urbanismo) Universidade de Brasília (UNB), Brasília:2009.

SILVEIRA, A. L. R. C. Parâmetros bioclimáticos para avaliação de conjuntos habitacionais multifamiliares na região tropical subúmida do Brasil. Tese. (Doutorado em... INFORMAR), Universidade de Brasília (UNB), 2007.

UGEDA JR. J. C. Clima Urbano e Planejamento na Cidade de Jales (SP). Universidade Estadual Paulista (UNESP). Tese (Doutorado em Geografia), 2011.

Recebido para publicação em Agosto de 2017 Aceito para publicação em Dezembro de 2017 